J. Product. \& Dev., 19(3):287-297(2014)

\title{
COMBINING ABILITY FOR QUALITY TRAITS IN CYTOPLASMIC MALE STERILITY BASED HYBRIDS OF CARROT (Daucus carota L.)
}

\author{
Nouri Alamin Kushlaf* and Pritam Kalia** \\ * Plant Production Dept., Faculty of Veterinary and Agricultural Sciences, Zawia \\ University, Zawia, Libya. \\ **Division of Vegetable Science, Indian Agricultural Research Institute, New \\ Delhi-110012
}

\begin{abstract}
This study was conducted during 2009-2010 and 2010-2011 seasons at the Division of Vegetable Science, Indian Agricultural Research Institute, New Delhi, India. Fifteen parents (five cytoplasmic male sterility (CMS) lines and ten fertile lines) and 50 hybrids of carrot were used for this study. Combining ability were assessed in a randomized complete block design with three replications. Substantial genetic variability were existed among parents and their $F_{1} s$ for eleven characters studied. Among the 15 parents, the line IPC53 recorded the highest positive significant gca effect for four characters (reducing sugar, total carotene, ascorbic acid, and $\mathrm{Cu}$ ) and the second highest significant gca effects for five characters (K, P, Mn, Zn and Fe). Also, the top six hybrids with high per se performance (IPC53 x IPC122, IPC126 x IPC116, IPC98 x IPC16, IPC55 x IPC16, IPC98 x IPC13 Red and IPC126 $x$ IPC76) exhibited high sca effects for total carotene.

Conclusively, both GCA and SCA effects were highly significant for all the characters. The variances due to SCA were greater than the GCA variances for most the studied characters except total carotene. Among 50 hybrids, the hybrid (IPC126 x IPC76) showed one from the five best (SCA) for most of the studied quality characters.
\end{abstract}

Key words: Carrot, combining ability, quality, CMS based hybrids , gca effects

\section{INTRODUCTION:}

Carrot (Daucus carota L.) belongs to the Family Umbelliferae. The carrot is believed to have originated in Asia and now under cultivation in many countries. The carrot is an important vegetable because of its large yield per unit area throughout the world and its increasing importance as human food (Ahmad et al., 2005). Carrots are widely used as a fresh market or processed product. It is characterized by high concentrations of health promoting 
compounds, especially carotenoid, which is a group of yellow, orange, and red phytochemicals found in most plants ( Pauleikhoff et al., 2001). Purple carrot color is due to anthocyanins. The marketable yields are low due to lack of improved, uniform, self core, slow bolting, high quality root varieties. Carotene and total soluble solids are some of the factors determining the quality of carrots which can be indicative of nutritional value and consumer acceptability for taste and flavour (Rubatzky et al., 1999).

The color of carrot was an important adjective during its domestication as a root crop. Carrot is known as an orange vegetable but other carrot colors exist some predating orange carrots. The first carrots were yellow and purple followed by the development of orange carrots in the $15^{\text {th }}$ and $16^{\text {th }}$ centuries (Simon et al., 2008). It contains several mineral and trace elements, like of calcium, potassium, zinc and iron, which are essential nutrients.

Hybrid culture in vegetables have gained importance in the recent past especially due to high production, productivity and uniform maturity demanding one time harvest. Thus, it has much more importance in root vegetables like carrot where crop demands one time harvest. Hybrids often exhibit heterosis, more commonly known as hybrid vigour, whereby hybrid progeny exhibit superior growth characteristics relative to either of the parental lines. Significant heterosis for earliness and yield has been registered reported for major root vegetable crops including carrot (Kalia, 2004). Since 1970, carrot breeding has been dominated by the method based on heterosis (Gorecka et al., 2005). Since 1960 's, use of male sterilities allowed the creation of the first $\mathrm{F}_{1}$ hybrids.

Breeding of carrot hybrids is based on the development of inbreds and incorporation of CMS lines crossed with male fertile pollinators. In carrot two distinct CMS phenotypes, the petaloid and brown anther types have been observed. The phenotype of brown anther CMS is characterized by brownish anthers, in which pollen growth ceases prior to maturation of this phenotype. In contrast, the petaloid CMS types have petals or petal-like structures instead of anther organs, which also do not form functional pollen. At least two different types of petaloid CMS, the Cornell and the Wisconsin Wild types, have been identified in carrots (Morelock et al., 1996). Recently, CMS has been transferred/introgressed into improved tropical carrot genetic backgrounds (Kalia, 2004). CMS is a maternally inherited trait that prevents the production of viable pollen without affecting female fertility (Banga and Bennekom, 1964). CMS systems can be of considerable value in facilitating efficient hybrid seed production save time and effort as it is a maternally inherited trait that is often associated with unusual open reading frames (ORFs) found in mitochondrial genomes (Chase and Babay-Laughnan, 2004).

Therefore, the aim of carrot breeding depend on the production method and the intended use. Breeders select for high carotene and sugar content, low 
nitrogen content, special root shapes, shape of crown, colour of phloem and xylem, smooth skin, early maturity, yield, tenderness, colour of leaves and storage ability.

\section{MATERIALS AND METHODS}

The preset investigation entitled "Studies on cytoplasmic male sterility mediated heterosis and combining ability in carrot (Daucus carota L.)", was undertaken at experimental plots of Division of Vegetable Science, Indian Agricultural Research Institute, New Delhi-110 012 during winter seasons of the year 2009-2010 and 2010-2011. Combining ability were assessed in a randomized complete block design with three replications.

This study was used for including five CMS lines (IPC98, IPC53, IPC 55, IPC126 black and IPC11 orange), and ten fertile lines (IPC75, IPC76, IPC104, IPC13 red, IPC16, IPC25, IPC123, IPC116, IPC34 and IPC122), and 50 hybrids, observations were recorded on individual plant basis at the appropriate crop growth stage and data on total sugar and reducing sugar contents of roots were estimated by Land and Eynon's volumetric method (Horwitz, 1980), total soluble solids (TSS) from each root was measured using a Hand Refractometer and the results was expressed as ${ }^{\circ}$ Brix at $20^{\circ} \mathrm{C}$. Carotenoids content was estimated as methods of Vitamin Assay (1966) outlined by Ranganna (1997). Ascorbic acid content was determined by the method as described by MattkJohn (1970). For mineral analyses, Horwitz, (1980) method was used for sample preparation, digestion and estimation of minerals particularly phosphorus $(\mathrm{P})$, potassium $(\mathrm{K})$, manganese $(\mathrm{Mn})$, zinc $(\mathrm{Zn})$, copper $(\mathrm{Cu})$ and iron $(\mathrm{Fe})$ with minor modifications.

\section{RESULTS}

For TSS, four lines exhibited significant gca effects, two lines were in positive desirable direction (IPC53 and IPC126) and the other two were in negative (IPC55 and IPC11orange) direction. Line IPC126 (0.54) exhibited significantly higher magnitude of positive gca effects for TSS among the parent genotypes (Table 1). Out of 10 testers under investigation, six testers had significant positive gca effects for TSS, while four testers had negative significant gca effects (Table 2). For total sugar, only one line (IPC126) and five testers showed significant positive gca effects while, other lines and testers exhibited significant negative gca effects. Parent IPC126 showed a highest (1.04) positive and highly significant gca effect.

In case of reducing sugar, four lines exhibited significant gca effects, of which only one (IPC53) exhibited significant positive gca effect. Among testers, the parents IPC75, IPC104 and IPC25 registered significant positive 
Table 1: GCA effects of females parents for eleven quality characters

\begin{tabular}{|c|c|c|c|c|c|c|}
\hline Genotypes & IPC 98 & IPC53 & IPC55 & IPC126 & IPC11 Orange & SE \\
\hline TSS & -0.03 & $0.22 * *$ & $-0.27 * *$ & $0.54 * *$ & $-0.46^{* *}$ & 0.03 \\
\hline Total sugar & $-0.25 * *$ & $-0.12 * *$ & $-0.23 * *$ & $1.04 * *$ & $-0.44 * *$ & 0.02 \\
\hline Reducing sugar $(\%)$ & $-0.04 * *$ & $0.22 * *$ & 0.0 & $-0.06^{* *}$ & $-0.13^{* *}$ & 0.01 \\
\hline Totalcarotene & $1.19 * *$ & $1.24 * *$ & $1.12 * *$ & $-4.66 * *$ & $1.10 * *$ & 0.01 \\
\hline Ascorbic acid & $0.48 * *$ & $1.28 * *$ & $0.93 * *$ & $-2.97 * *$ & 0.29 & 0.07 \\
\hline $\mathbf{K}$ & $-3.60 * *$ & $9.65 * *$ & $-12.17 * *$ & -1.87 & $8.00 * *$ & 1.82 \\
\hline $\mathbf{P}$ & $0.82 * *$ & $3.97 * *$ & $-2.24 * *$ & $-3.07 * *$ & $0.50 * *$ & 0.04 \\
\hline Mn & $0.26^{* *}$ & $2.10 * *$ & $-0.85^{* *}$ & $-0.29 * *$ & $-1.23 * *$ & 0.04 \\
\hline $\mathbf{Z n}$ & $-1.21 * *$ & $1.33^{* *}$ & -0.11 & $1.16^{* *}$ & $-1.17 * *$ & 0.12 \\
\hline $\mathbf{C u}$ & $1.33 * *$ & $2.00 * *$ & $-1.37 * *$ & $-1.20 * *$ & $-0.77 * *$ & 0.12 \\
\hline $\mathrm{Fe}$ & $0.55^{* *}$ & $1.40^{* *}$ & $-1.15^{* *}$ & $0.48 * *$ & $-1.28 * *$ & 0.05 \\
\hline
\end{tabular}

gca effects and IPC13 red, IPC16, IPC116, IPC34 and IPC122, exhibited significant negative gca effects. Out of 50 crosses 22,23 and 25 crosses had shown significant positive sca effects and 21, 21 and 19 had shown significant negative sca effects, for TSS, total sugar and reducing sugar, respectively. For the TSS, sca effects ranged from -1.01 to 1.01, total sugar from -0.85 to 0.99 and for reducing sugar from -0.96 to 0.6 (Table 3 ).

In respect to the CUPRAC, all the five lines selected for the present investigation study showed highly significant gca effects, only IPC126 was positive significant gca effects. Parent IPC126 (61.23) showed the highest positive significant gca effects. Out of ten testers under investigation, three testers (IPC75, IPC25, and IPC116) had negative significant gca effects, and other lower testers exhibited positive significant gca effect. For FRAP, all the five lines and ten testers showed significant gca effects. For FRAP, seven and eight parents has displayed positive and negative gca effects, respectively. IPC126 (63.44) exhibited maximum significant positive gca effect. However, other our lines showed significant negative gca effects. 23 and 25 crosses had shown significant positive and negative sca effect for CUPRAC and 26 and 21 for FRAP, with sca effects ranging from -55.4 to 36.15 and from -38.4 to 37.18 for CUPRAC and FRAP, respectively.

In case of total carotene, all the lines chosen for the study exhibited positive significant gca effects, out of which only IPC126 exhibited negative gca effect. Nine testers showed significant gca effects, among of them four 
Table 3: Range of SCA and five top crosses of SCA effect for eleven quality characters

\begin{tabular}{|c|c|c|c|}
\hline Character & Range of SCA & Crosses & SCA value \\
\hline TSS & -1.01 To 1.01 & $\begin{array}{l}\text { IPC126 x IPC76 } \\
\text { IPC53 x IPC116 } \\
\text { IPC55 x IPC16 } \\
\text { IPC98 x IPC25 } \\
\text { IPC53 x IPC75 }\end{array}$ & $\begin{array}{l}1.01 \\
0.74 \\
0.73 \\
0.71 \\
0.68\end{array}$ \\
\hline Total sugar & -0.85 To 0.99 & $\begin{array}{l}\text { IPC53 x IPC75 } \\
\text { IPC53 x IPC122 } \\
\text { IPC53 x IPC116 } \\
\text { IPC126 x IPC76 } \\
\text { IPC126 x IPC16 } \\
\text { IPC55 x IPC16 } \\
\end{array}$ & $\begin{array}{l}0.99 \\
0.75 \\
0.65 \\
0.56 \\
0.55\end{array}$ \\
\hline Reducing sugar (\%) & -0.96 To 0.6 & $\begin{array}{l}\text { IPC126 x IPC122 } \\
\text { IPC55 x IPC16 } \\
\text { IPC98 x IPC34 } \\
\text { IPC53 x IPC116 } \\
\text { IPC126 x IPC76 }\end{array}$ & $\begin{array}{c}0.6 \\
0.58 \\
0.57 \\
0.57 \\
0.56 \\
\end{array}$ \\
\hline Total carotene & -1.07 To 1.07 & $\begin{array}{l}\text { IPC126 x IPC116 } \\
\text { IPC126 x IPC123 } \\
\text { IPC98 x IPC13 Red } \\
\text { IPC53 x IPC25 } \\
\text { IPC55 x IPC75 }\end{array}$ & $\begin{array}{l}1.07 \\
0.92 \\
0.88 \\
0.82 \\
0.82\end{array}$ \\
\hline Ascorbic acid & -1.83 To 1.5 & $\begin{array}{l}\text { IPC126 x IPC75 } \\
\text { IPC98 x IPC116 } \\
\text { IPC98 x IPC13 Red } \\
\text { IPC53 x IPC25 } \\
\text { IPC11 Orange x IPC76 }\end{array}$ & $\begin{array}{l}1.50 \\
1.22 \\
1.10 \\
1.06 \\
1.06\end{array}$ \\
\hline $\mathbf{K}$ & -81.9 То 83.54 & $\begin{array}{l}\text { IPC98 x IPC75 } \\
\text { IPC11 Orange x IPC76 } \\
\text { IPC126 x IPC76 } \\
\text { IPC53 x IPC25 } \\
\text { IPC55 x IPC116 }\end{array}$ & $\begin{array}{l}83.54 \\
69.60 \\
57.14 \\
46.95 \\
45.54\end{array}$ \\
\hline $\mathbf{P}$ & -9.2 To 16.63 & $\begin{array}{l}\text { IPC98 } \times \text { IPC104 } \\
\text { IPC98 x IPC75 } \\
\text { IPC98 x IPC123 } \\
\text { IPC53 x IPC25 } \\
\text { IPC53 } \times \text { IPC122 } \\
\text { IPC126 } 1 \text { IPC76 }\end{array}$ & $\begin{array}{c}16.63 \\
14.81 \\
10.67 \\
8.62 \\
7.76\end{array}$ \\
\hline Mn & -5.81 To 5.51 & $\begin{array}{l}\text { IPC98 x IPC75 } \\
\text { IPC98 x IPC34 } \\
\text { IPC53 x IPC25 } \\
\text { IPC11 Orange x IPC76 } \\
\text { IPC11 Orange x IPC123 } \\
\text { IPC126 x IPC76 }\end{array}$ & $\begin{array}{l}5.51 \\
3.43 \\
3.24 \\
3.12 \\
3.03\end{array}$ \\
\hline
\end{tabular}




\begin{tabular}{|c|c|c|c|}
\hline Character & Range of SCA & Crosses & SCA value \\
\hline $\mathbf{Z n}$ & -3.19 To 4.47 & $\begin{array}{l}\text { IPC } 98 \times \text { IPC75 } \\
\text { IPC } 126 \text { x IPC76 } \\
\text { IPC126 x IPC104 } \\
\text { IPC53 x IPC25 } \\
\text { IPC55 x IPC116 }\end{array}$ & $\begin{array}{l}4.47 \\
4.44 \\
3.04 \\
3.01 \\
2.71\end{array}$ \\
\hline $\mathbf{C U}$ & -2.8 To 3.53 & $\begin{array}{l}\text { IPC98 x IPC123 } \\
\text { IPC55 x IPC76 } \\
\text { IPC53 x IPC13 Red } \\
\text { IPC98 x IPC25 } \\
\text { IPC53 x IPC25 } \\
\text { IPC126 x IPC76 }\end{array}$ & $\begin{array}{l}3.53 \\
2.03 \\
1.93 \\
1.93 \\
1.80\end{array}$ \\
\hline $\mathbf{F e}$ & -5.65 То 7.61 & $\begin{array}{l}\text { IPC98 x IPC16 } \\
\text { IPC53 x IPC25 } \\
\text { IPC55 x IPC116 } \\
\text { IPC11 Orange x IPC104 } \\
\text { IPC11 Orange x IPC123 } \\
\text { IPC126 x IPC76 }\end{array}$ & $\begin{array}{l}7.61 \\
4.94 \\
4.39 \\
4.27 \\
4.26\end{array}$ \\
\hline
\end{tabular}

testers had positive significant gca. For the lycopene, all the five lines and ten testers selected for the study recorded significant gca effects. Four parents and six testers displayed positive and negative gca effects. The range of sca effects was from -1.07 to 1.07 for total carotene. Out of 23 crosses had shown significant positive sca effects and 25 had shown significant negative sca effects for total carotene (Table, 3 ).

It is clear in Table, 3 that four out of five lines exhibited significant gca effects for ascorbic acid, ranging from -2.97 (IPC126) to 1.28 (IPC53). Among testers, nine parents exhibited significant gca effects, of these IPC75, IPC76, IPC116 and IPC34 registered significant positive gca effects and IPC104, IPC16, IPC25, IPC123 and IPC122 exhibited significant negative gca effects. 18 and 15 crosses had shown significant positive and negative sca effects, respectively. For Potassium (K), four lines exhibited significant gca effects, ranging from -12.17 (IPC55) to 9.65 (IPC53). Two of them exhibited significant positive and two negative gca effects. Among 10 testers, 9 parents exhibited significant gca effects, of these IPC75, IPC76, IPC104, IPC16 and IPC123 registered significant positive gca effects, whereas IPC13 red, IPC25, IPC116 and IPC122 exhibited significant negative gca, effects. For phosphorus (P), three lines were found to be significantly positive while, other two lines IPC 55 (-2.24) and IPC126 (3.07) recorded significantly negative gca effects. Out of ten testers, five testers were significantly positive and other five testers displayed significantly negative gca effects. For manganese (Mn), IPC53 and IPC98 
had highly significant positive gca and other three exhibited highly significant negative gca effects. All testers exhibited significant gca effect of which, five were in positive and five were in negative direction. Four lines exhibited significant gca effects for zinc (Zn), varied from -1.21 (IPC98) to 1.33 (IPC53). Two of them exhibited significant positive and two exhibited negative gca effects. Among testers, 8 parents exhibited significant gca effects, of these IPC75 and IPC123 registered significant positive gca effects and other six exhibited significant negative gca effects. The lines, which contributed significant positive gca effects for copper $(\mathrm{Cu})$ were IPC98 (1.33) and IPC53 (2.00) and other three exhibited negative gca effects. Only two testers, IPC13red (0.63) and IPC16 (0.90) had significant positive gca effects while, other five crosses exhibited significant negative sca effects. Concerning iron (Fe), three lines IPC98 (0.55), IPC53 (1.40) and IPC126 (0.48) were found to have significantly positive gca effect while, other two lines IPC55 $(-1.15)$ and IPC11 orange $(-1.28)$ exhibited significantly negative gca effects. Three testers, IPC16 (0.47), IPC123 (4.42) and IPC122 (1.31) were the significantly positive general combiners and remaining had negative gca effects. Out of 50 crosses 23, 21, 25, 14, 10 and 26 crosses had shown significant positive sca effects and 21, 28, 23, 17, 12 and 22 had shown significant negative sca effects for $\mathrm{K}, \mathrm{P}, \mathrm{Mn}, \mathrm{Zn}, \mathrm{Cu}$ and Fe, respectively. The range of sca effects was from -81.9 to $83.54,-9.2$ to $16.63,-5.81$ to $5.51,-3.19$ to $4.47,-2.8$ to 3.53 and from -5.65 to 7.61 for $\mathrm{K}, \mathrm{P}, \mathrm{Mn}, \mathrm{Zn}, \mathrm{Cu}$ and $\mathrm{Fe}$, respectively (Table 3).

\section{DISCUSSION}

Among the 15 parents, the line of IPC53 recorded the highest positive significant gca effect for four quality characters (reducing sugar, total carotene, ascorbic acid, and $\mathrm{Cu}$ ) and also exhibited second highest significant gca effects for five characters (K, P, Mn, $\mathrm{Zn}$ and $\mathrm{Fe}$ ). Furthermore, the line of IPC126 recorded the highest positive significant gca effect for two characters ( TSS and total sugar). This is true with the parents IPC53, and IPC126. This is consistent with what recommended by (Duan et al., 1996) on carrot.

Carotenes content of roots is the most important quality desired by the carrot breeder. In the present study, the top six hybrids with high per se performance (IPC53 x IPC122, IPC126 x IPC116, IPC98 x IPC16, IPC55 x IPC16, IPC98 x IPC13 Red and IPC126 x IPC76) had also, exhibited high sca effects for total carotene. While, the hybrids IPC53 x IPC122, IPC126 x IPC116, IPC98 x IPC16 and IPC55 x IPC16 also exhibited significant sca effects for TSS, total sugars, reducing sugars and Mn. Regarding 
the minerals content, the hybrid IPC126 x IPC116 had a high positive significant sca effect for $\mathrm{K}, \mathrm{P}, \mathrm{Mn}, \mathrm{Zn}, \mathrm{Cu}$ and $\mathrm{Fe}$ contents. While, the hybrid IPC126 x IPC76 also exhibited high significant sca effects for some minerals content $(\mathrm{K}, \mathrm{P}, \mathrm{Zn}$ and $\mathrm{Fe})$. In case of ascorbic acid, the hybrids IPC126 x IPC116 and IPC126 x IPC76 had high significant positive sca effect. The hybrids IPC53 x IPC122 and IPC53 x IPC25 involved positive $\mathrm{x}$ positive general combiners with parent IPC53 having the highest and significant gca effect, demonstrating its value as good general combiner for the carotenes content. Further, these two hybrids (IPC53 x IPC122 and IPC53 x IPC25) having positive $x$ positive gca effects revealed that the high sca effects in these crosses were mainly through additive genes effects. Therefore, the best option for improvement is (identification of transgressive segregant) based on (sca) effects which may lead to isolation of promising lines in advanced generation with high carotenes content of carrot. For this trait similar results have been reported by Duan et al., (1996),on carrot and Chandel et al. (2002) and Song and Wei (1996) on radish.

Conclusively, both GCA and SCA effects were highly significant for all the characters. The variances due to SCA were greater than the GCA variances for most the studied characters except CUPRAC, FRAP and total carotene. Among 50 hybrids, the hybrid (IPC126 x IPC76) showed one from the five best (SCA) for most of the studied quality characters.

\section{REFERENCES}

Ahmad, B.; Hassan, S. and Bakhsh, K. (2005). Factors affecting yield and profitability of carrot in two districts of Punjab. Internat. J. Agric. Biol., 7: 794-798.

Banga, J.P. and Bennekom, J. L. (1964). Genetical analysis of male sterility in carrots Daucus carota L. Euphytica., 19: 263-269.

Chandel, K.S.; Sharma, V.K. and Pathania, N.K. (2002). Line x tester analysis for the study of combining ability in radish (Raphanus sativus L.). Veg. Sci., 29(2): 110-112.

Chase, C. and Babay-Laughnan, S. (2004). Cytoplasmic male sterility and fertility restoration by nuclear genes. In: H. Daniell and C. Chase (eds.), molecular biology and biotechnology of plant organelles, Dordrecht, The Netherlands, Kluwer Academic Publishers, pp. 593-622.

Duan, Y.; Yong, W., Xiaoyun, R. and Gangqiang, D. (1996). Analyze of heterosis and combining ability for main yield characteristics in carrot. China Vegetables, 1996-2002. 
Gorecka, K.; Krzyanowska, D. and Gorecki, R. (2005). The influence of several factors on the efficiency of androgenesis in carrot. J. Appl. Genet., 46 (3): 265-269.

Horwitz, W. (1980). Official methods of analysis of the association of official analytical chemists. ( $13^{\text {th }}$ edition). General of association of official agricultural chemists, pp. 128-129.

Kalia, P. (2004). Root vegetable crops. J. New Seeds, 6: 247-275.

Mattk- John (1970).Colorimetric determination of phosphorus in soil and plant materials with ascorbic acid and determination of ascorbic acid with phenol. Soil Sci., 109:214-220.

Morelock, T. E.; Simon, P.W. and Peterson, C.E. (1996). Wisconsin wild: another petaloid male-sterile cytoplasm for carrot. Hortscience, 31(5): 887-888.

Pauleikhoff, D.; Van Kuijfk, F.J. and Bird, A.C. (2001). Macular pigment and age-related macular degeneration. Ophtalmologe, 98: 511-519.

Ranganna, S. (1997). Plant Pigments. In: Manual of Analysis of Fruit and Vegetable Products. Ranganna, S. (Ed.). TaTa McGraw-Hill Publishing Co., Ltd., New Delhi.

Rubatzky, V.E.; Quiros, C.F. and Simon P.W. (1999). Carrots and related vegetable Umbelliferae. CABI Publishing, pp. 22-30.

Simon, P.W.; Tanumihardjo, S.A.; Clevidence, B.A. and Novotny, J.A. (2008). Role of color and pigments in breeding, genetics, and nutritional improvement of carrots. In color quality of fresh and processed foods. American Chemical Society Books. Washington, DC: pp. 151-165.

Song, M.X. and Wei, S.L. (1996). On the heterosis of hybrid radish and the strategy for parent choice. Agriculture - Zhejiangensis, 8 (1): 46-49.

\section{قدرة الإنتلاف في دراسة العقم الذكري السيتوبلازمي في هجن الجزر}

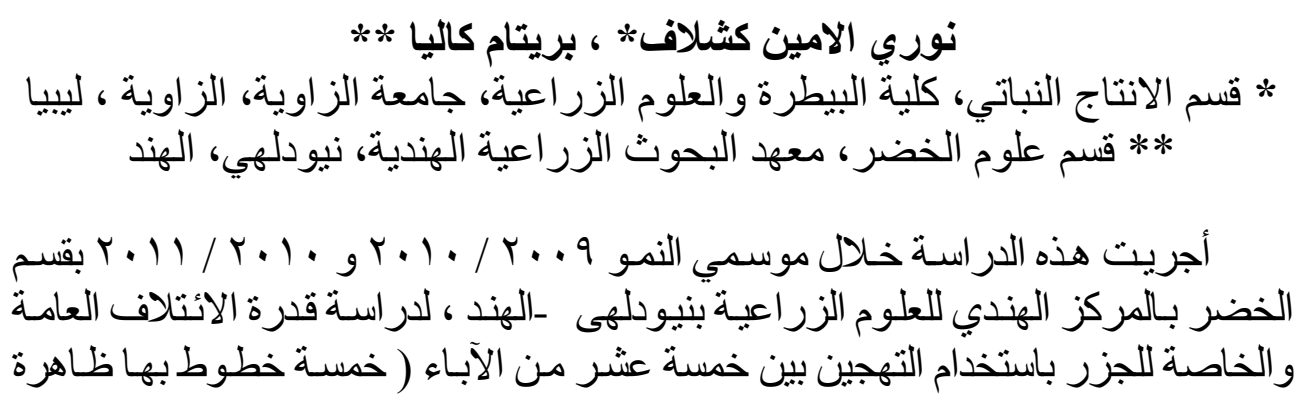


العقم الذكري السيتوبلازمي و عشرة خطوط خصبة )هو التى نتج عنها خمسون هجين ، في

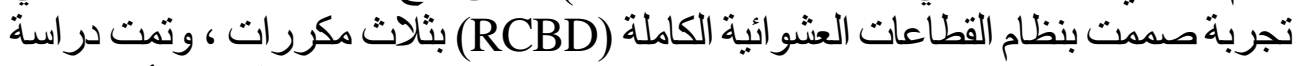

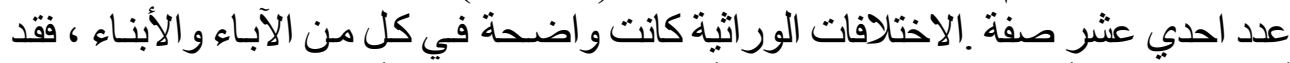

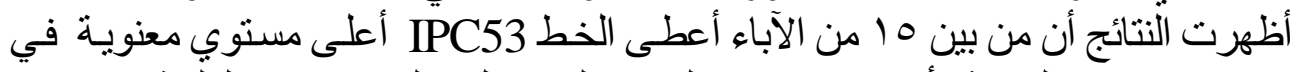

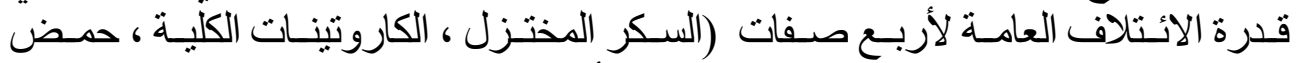

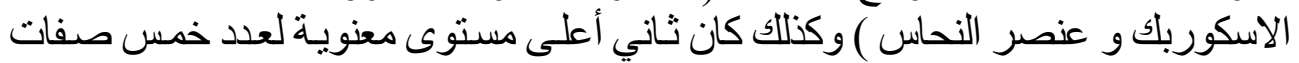

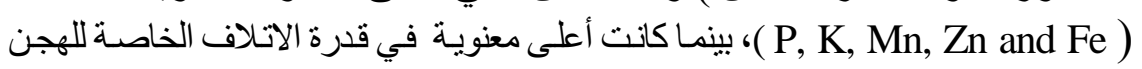
IPC98 x ,IPC55 x IPC16, IPC98 x IPC16, IPC126 x IPC116 IPC53 x IPC122,) (IPC126 x IPC76, IPC13Red كلا من قدرة الائتلاف العامـة والخاصـة قد أعطت معنويـة عاليـة في كل الصـفات

$$
\text { المدروسة. }
$$

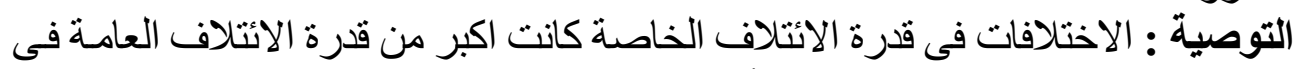

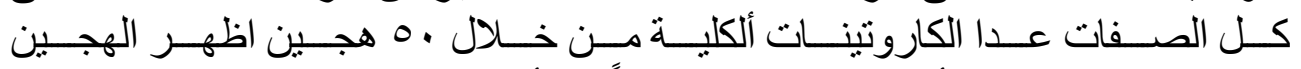

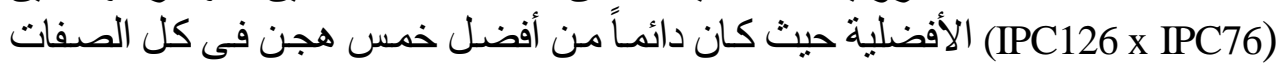
المدروسة . 
